Research Paper

\title{
The efficiency and safety of high-dose vitamin C in patients with COVID-19: a retrospective cohort study
}

\author{
Dengfeng $\mathrm{Gao}^{1,{ }^{*}}$, Min $\mathrm{Xu}^{1,{ }^{*}}$, Gang Wang${ }^{2}$, Jianrui $\mathrm{Lv}^{3}$, Xiaorong $\mathrm{Ma}^{4}$, Yonghong Guo5 , Dexin

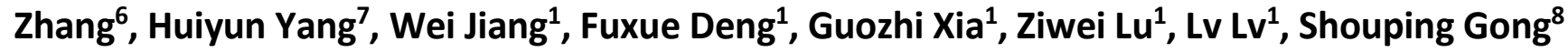 \\ ${ }^{1}$ Department of Cardiology, The Second Affiliated Hospital, Xi'an Jiaotong University, Xi'an, Shaanxi, P.R. China \\ ${ }^{2}$ Department of Critical Care, The Second Affiliated Hospital, Xi' an Jiaotong University, Xi'an, Shaanxi, P.R. China \\ ${ }^{3}$ Department of Anesthesiology, The Second Affiliated Hospital, Xi'an Jiaotong University, Xi'an, Shaanxi, P.R. \\ China \\ ${ }^{4}$ Department of Hematology, The Second Affiliated Hospital, Xi'an Jiaotong University, Xi' an, Shaanxi, P.R. China \\ ${ }^{5}$ Department of Infectious Diseases, The Second Affiliated Hospital, Xi'an Jiaotong University, Xi' an, Shaanxi, P.R. \\ China \\ ${ }^{6}$ Department of Respiratory and Critical Care, The Second Affiliated Hospital, Xi'an Jiaotong University, Xi'an, \\ Shaanxi, P.R. China \\ ${ }^{7}$ Department of Nursing, The Second Affiliated Hospital, Xi'an Jiaotong University, Xi'an, Shaanxi, P.R. China \\ ${ }^{8}$ Department of Neurosurgery, The Second Affiliated Hospital, Xi'an Jiaotong University, Xi'an, Shaanxi, P.R. China \\ *Equal contribution
}

Correspondence to: Shouping Gong, Dengfeng Gao; email: shpingg@mail.xjtu.edu.cn, gaomedic@mail.xjtu.edu.cn Keywords: coronavirus disease 2019, COVID-19, ascorbic acid, mortality, safety

Received: October 28, $2020 \quad$ Accepted: January 4, 2021

Published: February 26, 2021

Copyright: (C) 2021 Gao et al. This is an open access article distributed under the terms of the Creative Commons Attribution License (CC BY 3.0), which permits unrestricted use, distribution, and reproduction in any medium, provided the original author and source are credited.

\section{ABSTRACT}

Background: The inflammatory reaction is the main cause of acute respiratory distress syndrome and multiple organ failure in patients with Coronavirus disease 2019 , especially those with severe and critical illness. Several studies suggested that high-dose vitamin $\mathrm{C}$ reduced inflammatory reaction associated with sepsis and acute respiratory distress syndrome. This study aimed to determine the efficacy and safety of high-dose vitamin $\mathrm{C}$ in Coronavirus disease 2019.

Methods: We included 76 patients with Coronavirus disease 2019, classified into the high-dose vitamin $\mathrm{C}$ group (loading dose of $6 \mathrm{~g}$ intravenous infusion per $12 \mathrm{hr}$ on the first day, and $6 \mathrm{~g}$ once for the following 4 days, $\mathrm{n}=46$ ) and the standard therapy group (standard therapy alone, $n=30$ ).

Results: The risk of 28-day mortality was reduced for the high-dose vitamin $\mathrm{C}$ versus the standard therapy group (HR=0.14, 95\% Cl, 0.03-0.72). Oxygen support status was improved more with high-dose vitamin $\mathrm{C}$ than standard therapy (63.9\% vs $36.1 \%$ ). No safety events were associated with high-dose vitamin $\mathrm{C}$ therapy.

Conclusion: High-dose vitamin $\mathrm{C}$ may reduce the mortality and improve oxygen support status in patients with Coronavirus disease 2019 without adverse events.

\section{INTRODUCTION}

Coronavirus disease 2019 (COVID-19) has spread rapidly worldwide [1-5]. As of July 2, 2020, 10,533,779 cases were reported and COVID-19 caused
512,842 death worldwide according to data from the World Health Organization (WHO). More than 50,000 individuals were critically ill [6]. Severe and critically ill patients often have dyspnea and/or hypoxemia and can even rapidly progress to acute respiratory distress 
syndrome (ARDS), septic shock, and multiple organ failure, resulting in high mortality. The mortality rate ranges from $4 \%$ to $28 \%$ [7-12].

Previous studies have reported clinical characteristics of patients with COVID-19 [7-9]. Studies showed a rapid and massive production of many cytokines called a cytokine "storm" or inflammatory "storm" in confirmed COVID-19 patients [7-9]. The production of oxygen free radicals leads to microvascular endothelial injury and increased permeability of the microvasculature, resulting in increased exudation, which may be important causes of ARDS and multiple organ failure.

Physicians and biologists all over the world have been looking for drugs for COVID-19. However, no effective antiviral therapy or vaccine has been confirmed. Recently, several clinical trials have investigated therapeutic drugs, [13-19] but their effectiveness and safety are still controversial.

Early studies [20, 21] reported that the application of vitamin $\mathrm{C}$ in animal models of sepsis could improve capillary circulation, microvascular barrier function and arteriolar reactivity caused by vasoconstrictors. As a tissue antioxidant, vitamin $\mathrm{C}$ can effectively remove oxygen free radicals produced by myocardial tissues, macrophages and ischemia-reperfusion tissues. These free radicals are the initiating factors of Keshan disease $[22,23]$. Physicians in our hospital successfully used high-dose vitamin $\mathrm{C}$ with patients with acute Keshan disease and cardiogenic shock and reduced the mortality from $86 \%$ to $5 \%$ [24-26]. In recent years, physicians have used vitamin $\mathrm{C}$ to treat various serious inflammatory diseases, especially ARDS and sepsis [27]. In addition, the high-dose vitamin $\mathrm{C}$ therapy in acute Keshan disease [24-26] and recent studies [2830] suggested that a early and short course from 3 to 5 days of high-dose vitamin $\mathrm{C}$ treatment could blocked the inflammatory reaction effectively. Observational studies suggested that nearly $40 \%$ of sepsis patients showed vitamin $\mathrm{C}$ deficiency, [27, 31] and the concentration of vitamin $\mathrm{C}$ in plasma of patients with early sepsis was inversely correlated with multiple organ dysfunction indicators [32]. A study of 167 patients with sepsis and ARDS suggested that mortality and intensive care unit stay were significantly reduced in the high-dose vitamin $\mathrm{C}$ group [28].

The clinical application of high-dose vitamin $\mathrm{C}$ is expected to improve the prognosis of patients by the production of powerful antioxidant free radicals and inhibition of vascular inflammatory exudation. Therefore, we explored the outcomes in patients hospitalized for COVID-19 who received high-dose vitamin $\mathrm{C}$ or standard therapy to demonstrate the efficiency and safety of high-dose vitamin C.

\section{RESULTS}

\section{The exclusion of participants}

Overall, 84 patients received high-dose vitamin $\mathrm{C}$ or standard therapy, but 8 were excluded because they were pregnant $(n=2)$, lactating $(n=1)$, had missing baseline information $(\mathrm{n}=1)$, received fewer than 5 days of highdose vitamin $\mathrm{C}(\mathrm{n}=3)$, or died within $24 \mathrm{hr}(\mathrm{n}=1)$.

\section{Baseline characteristics}

Table 1 shows the baseline characteristics of 76 patients: 46 with high-dose vitamin $\mathrm{C}$ and 30 standard therapy alone. A total of $48(63.2 \%)$ patients had a diagnosis of moderate COVID-19, and $28(36.8 \%)$ severe or critical disease. The median age was 61 years (IQR, 52 to 71), and the median duration of symptoms before therapy 12 days (IQR, 8 to 16). No patient received invasive mechanical ventilation at baseline; $40(52.6 \%)$ patients received high-flow oxygen or noninvasive positive pressure ventilation. The two therapy groups did not differ in baseline characteristics including laboratory data (Table 1, Supplementary Table 1).

\section{Mortality after high-dose vitamin $\mathrm{C}$ therapy and standard therapy}

Six $(7.9 \%)$ patients with severe or critical disease died at the end of 28 days; one (16.7\%) received high-dose vitamin C, and 5 (83.3\%) standard therapy. On KaplanMeier analysis, the risk of mortality was significantly reduced with high-dose vitamin $\mathrm{C}$ than standard therapy $(\mathrm{HR}=0.14,95 \% \mathrm{CI}, 0.03-0.72)$ (Figure 1). In patients with severe or critical disease and age > 60, the risk of mortality was lower for patients with high-dose vitamin $\mathrm{C}$ than that with standard therapy $(\mathrm{HR}=9.91,95 \% \mathrm{CI}, 1.82$ 54.00; HR=7.98, 95\% CI, 1.24-51.22) (Figure 2A, 2B).

\section{Oxygen support status after high-dose vitamin C therapy and standard therapy}

Over a median retrospective time of 18 days (IQR, 10 to 28), $36(47.4 \%)$ patients showed an improvement in oxygen support status, $23(63.9 \%)$ in the high-dose vitamin $\mathrm{C}$ group and 13 (36.1\%) in the standard therapy group (Table 2). For moderate cases $(n=48)$, oxygen support status was improved for 28 patients, and 17 (60.7\%) of them were in the high-dose vitamin $\mathrm{C}$ group and $11(39.3 \%)$ in the standard therapy group. For patients with severe or critical disease $(n=28)$, there were 8 patients who showed an improvement, and 6 $(75.0 \%)$ in the high-dose vitamin $\mathrm{C}$ group and 2 
Table 1. Clinical characteristics of patients at baseline.

\begin{tabular}{|c|c|c|c|c|}
\hline Characteristic & $\begin{array}{c}\text { Total } \\
(\mathrm{n}=76)\end{array}$ & $\begin{array}{c}\text { High-dose VitC } \\
(n=46)\end{array}$ & $\begin{array}{c}\text { Standard therapy } \\
(\mathrm{n}=\mathbf{3 0})\end{array}$ & $P$ value \\
\hline Disease severity — no. (\%) & & & & 0.609 \\
\hline Moderate & $48(63.2)$ & $28(60.9)$ & $20(66.6)$ & \\
\hline Severe or critical & $28(36.8)$ & $18(39.1)$ & $10(33.4)$ & \\
\hline Age, median (IQR) - years & $61(52-71)$ & $63(54-71)$ & $57(49-67)$ & 0.239 \\
\hline Male sex — no. (\%) & $35(46.1)$ & $21(45.7)$ & $14(46.7)$ & 0.931 \\
\hline Smoking history- no. (\%) & $8(10.5)$ & $5(10.9)$ & $3(10.0)$ & 0.904 \\
\hline \multicolumn{5}{|l|}{ Coexisting condition - no. (\%) } \\
\hline Diabetes & 15 (19.7) & $11(23.9)$ & $4(13.3)$ & 0.257 \\
\hline Hypertension & $22(28.9)$ & $16(34.8)$ & $6(20.0)$ & 0.165 \\
\hline Coronary heart disease & $5(6.6)$ & $3(6.5)$ & $2(6.7)$ & 0.980 \\
\hline Underlying lung disease & $6(7.9)$ & $4(8.7)$ & $2(6.7)$ & 0.748 \\
\hline Chronic liver disease & $4(5.3)$ & $3(6.5)$ & $1(3.3)$ & 0.543 \\
\hline Chronic kidney disease & $2(2.6)$ & $2(4.3)$ & 0 & 0.247 \\
\hline $\begin{array}{l}\text { Systolic blood pressure, median (IQR) - } \\
\mathrm{mmHg}\end{array}$ & $130(112-141)$ & $127(112-139)$ & $132(121-144)$ & 0.532 \\
\hline $\begin{array}{l}\text { Duration of symptoms before therapy, } \\
\text { median (IQR) - days }\end{array}$ & $12(8-16)$ & $13(8-20)$ & $10(8-12)$ & 0.180 \\
\hline Oxygen support category - no. (\%) & & & & 0.921 \\
\hline Low-flow oxygen & $36(47.4)$ & $22(47.8)$ & $14(46.7)$ & \\
\hline $\begin{array}{l}\text { High-flow oxygen or noninvasive positive } \\
\text { pressure ventilation }\end{array}$ & $40(52.6)$ & $24(52.2)$ & $16(53.3)$ & \\
\hline \multicolumn{5}{|l|}{ Treatment } \\
\hline Antiviral therapy & $72(94.7)$ & $42(91.3)$ & $30(100.0)$ & 0.097 \\
\hline Antibiotic therapy & $70(92.1)$ & $43(93.5)$ & $27(90.0)$ & 0.583 \\
\hline Corticosteroids & $28(36.8)$ & 15 (32.6) & $13(43.3)$ & 0.343 \\
\hline Gamma globulin & $23(30.3)$ & $13(28.3)$ & $10(33.3)$ & 0.638 \\
\hline Statins & $14(18.4)$ & $10(21.7)$ & $4(13.3)$ & 0.355 \\
\hline
\end{tabular}

IQR: interquartile range, VitC: vitamin C.

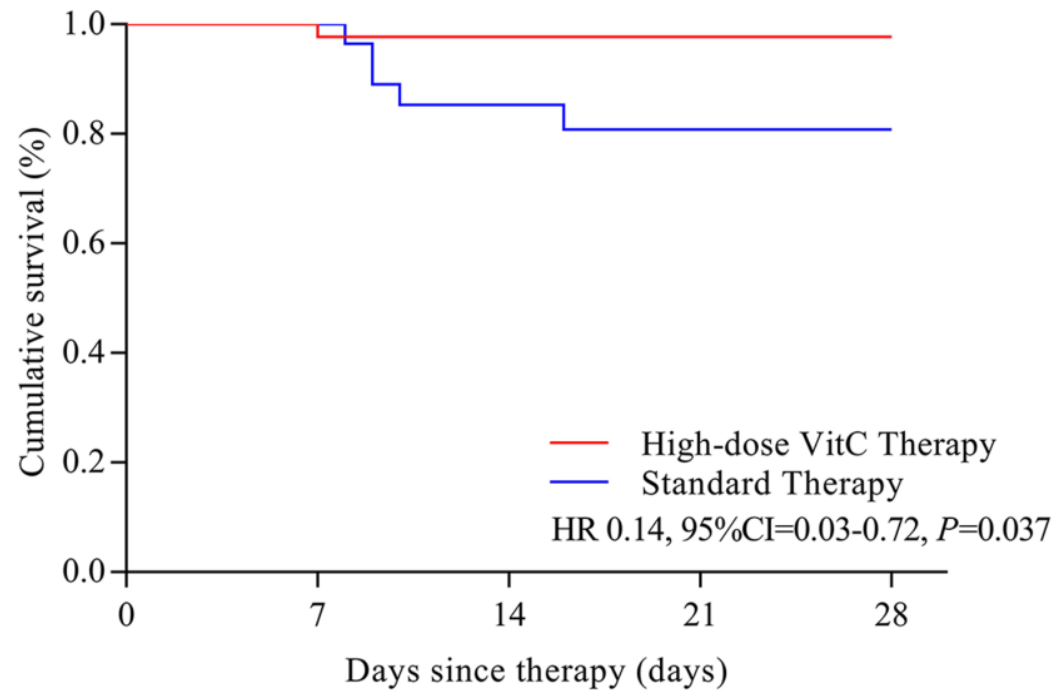

\section{Number at risk}

$\begin{array}{lllllr}\text { High-dose VitC Therapy } & 46 & 44 & 30 & 22 & 13 \\ \text { Standard Therapy } & 30 & 29 & 23 & 11 & 6\end{array}$

Figure 1. Overall survival with the two treatments in COVID-19 patients. The risk of mortality was significantly reduced with highdose vitamin C than standard therapy (HR=0.14, 95\% Cl, 0.03-0.72). VitC: vitamin C. 
A

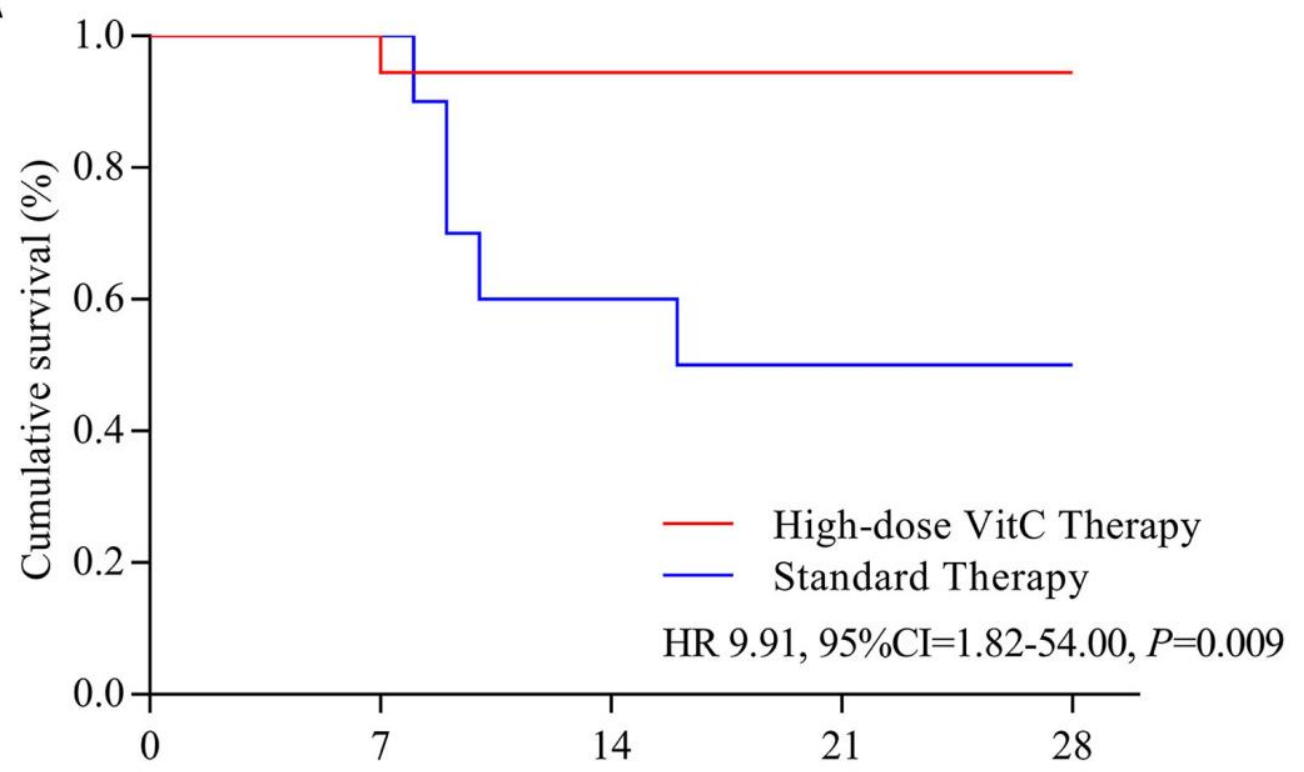

Number at risk

Standard Therapy $\quad 10$

Days since therapy (days) 
Table 2. Changes in oxygen-support status after treatment by disease type.

\begin{tabular}{lccccccc}
\hline & & \multicolumn{3}{c}{ High-dose VitC } & \multicolumn{3}{c}{ Standard therapy } \\
\cline { 3 - 7 } Oxygen support category & $\begin{array}{c}\text { Total } \\
(\mathbf{n = 7 6 )}\end{array}$ & $\begin{array}{c}\text { Total } \\
(\mathbf{n = 4 6 )}\end{array}$ & $\begin{array}{c}\text { Moderate } \\
(\mathbf{n = 2 8})\end{array}$ & $\begin{array}{c}\text { Severe } \\
\text { or } \\
\text { critical } \\
(\mathbf{n = 1 8})\end{array}$ & $\begin{array}{c}\text { Total } \\
(\mathbf{n = 3 0})\end{array}$ & $\begin{array}{c}\text { Moderate } \\
(\mathbf{n = 2 0})\end{array}$ & $\begin{array}{c}\text { Severe } \\
\text { or } \\
\text { critical } \\
(\mathbf{n}=\mathbf{1 0})\end{array}$ \\
\hline Low-flow oxygen - no. (\%) & $14(18.4)$ & $7(15.2)$ & $5(17.9)$ & $2(11.1)$ & $7(23.3)$ & $5(25.0)$ & $2(20.0)$ \\
High-flow oxygen - no. (\%) & $22(28.9)$ & $15(32.6)$ & $7(25.0)$ & $8(44.4)$ & $7(23.3)$ & $6(30.0)$ & $1(10.0)$ \\
Noninvasive positive pressure & $3(3.9)$ & $2(4.3)$ & 0 & $2(11.1)$ & $1(3.3)$ & 0 & $1(10.0)$ \\
ventilation - no. (\%) & $31(40.8)$ & $21(45.7)$ & $16(57.1)$ & $5(27.8)$ & $10(33.3)$ & $9(45.0)$ & $1(10.0)$ \\
Discharge - no. (\%) & $6(7.9)$ & $1(2.2)$ & 0 & $1(5.6)$ & $5(16.7)$ & 0 & $5(50.0)$ \\
Death - no. (\%) & $36(47.4)$ & $23(50.0)$ & $17(60.7)$ & $6(33.3)$ & $13(43.3)$ & $11(55.0)$ & $2(20.0)$ \\
Improvement -no. $(\%)$ & & & & & & &
\end{tabular}

Percentages of each oxygen support category were calculated with the number of patients at baseline as the denominator. VitC: vitamin C.

$(25.0 \%)$ in the standard therapy group (Table 2). Moreover, 31 patients were discharged at the end of day 18, $21(67.7 \%)$ in the high-dose vitamin $\mathrm{C}$ group, and $10(32.3 \%)$ in the standard therapy group.

\section{The subgroups benefit from high-dose vitamin $\mathrm{C}$ therapy}

In the high-dose vitamin $\mathrm{C}$ group, clinical improvement was better for patients $\leq 60$ years old than others (HR $=0.49$, 95\%CI, 0.25-0.99, Supplementary Figure 1A). Moreover, clinical improvement was better for patients who received low-flow oxygen (HR $=0.41$, 95\%CI, 0.20-0.84, Supplementary Figure 1B), and those with serum high-sensitivity C-reactive protein (hs-CRP) $<1 \mathrm{mg} / \mathrm{L}(\mathrm{HR}=0.26,95 \% \mathrm{CI}, 0.07-0.94$, Supplementary Figure 1C) than their counterparts.

\section{Changes in biomarkers of inflammation after high- dose vitamin $C$ therapy and standard therapy}

As compared with standard therapy, high-dose vitamin C reduced serum hs-CRP, procalcitonin (PCT) and interleukin-8 (IL-8) levels (Figure 3A, 3B, 3E). The serum interleukin-2 receptor (IL-2R), interleukin-6 (IL-6), and tumor necrosis factor- $\alpha$ (TNF- $\alpha$ ) levels were not affected remarkably in the high-dose vitamin $\mathrm{C}$ group (Figure 3C, 3D, 3F).

\section{Safety}

In total, $19(41.3 \%)$ patients in the high-dose vitamin C group, and $18(60.0 \%)$ in the standard therapy group showed adverse events (Table 3). Thrombocytopenia and increased total bilirubin events were common in the 2 groups. However, the incidence was lower in the high-dose vitamin $\mathrm{C}$ than the standard therapy group $(8.7 \%$ vs $13.3 \%$, $13.0 \%$ vs $30.0 \%) .6(7.9 \%)$ patients showed serious adverse events (respiratory failure or ARDS, shock and sepsis): 1 received high-dose vitamin $\mathrm{C}$ and 5 standard therapy. Moreover, respiratory failure or ARDS were more common in the standard therapy than the high-dose vitamin $\mathrm{C}$ group.

\section{DISCUSSION}

The world is currently facing the threat of the COVID-19 pandemic caused by SARS-CoV-2 infection. This epidemic continues to spread, and there are no vaccines or specific drugs approved or used to prevent or treat COVID-19. A large number of studies have confirmed that high-dose vitamin $\mathrm{C}$ can benefit patients with lung injury caused by various inflammatory diseases, especially ARDS and sepsis [27, 30, 33, 34]. This retrospective cohort study analyzed the efficiency and safety of high-dose vitamin C in patients with COVID-19. High-dose vitamin $\mathrm{C}$ could decrease mortality and improve the oxygen support status of COVID-19 patients.

Additionally, high-dose vitamin $\mathrm{C}$ remarkably reduced serum hs-CRP and PCT levels in COVID-19 patients (Figure 3A, 3B). CRP and PCT are acute-phase inflammatory proteins and related to the severity of body systematic infection. High CRP and PCT levels are associated with organ failure and increased mortality in patients admitted to intensive care units [35, 36]. A study [37] reported lower mortality in COVID-19 patients with reduced CRP level than persistently high CRP level. Jensen and colleagues [35] also found high PCT level as an early independent predictor of mortality for patients admitted to an intensive care unit. Recent reports suggested that COVID-19 patients had high levels of hs$\mathrm{CRP}$ and PCT [36, 38]. Vitamin C can directly reduce the production of reactive oxygen species, maintain endothelial barrier function and vasodilation, and downregulate the expression of proinflammatory modulators [39, 40]. Moreover, high-dose vitamin C 

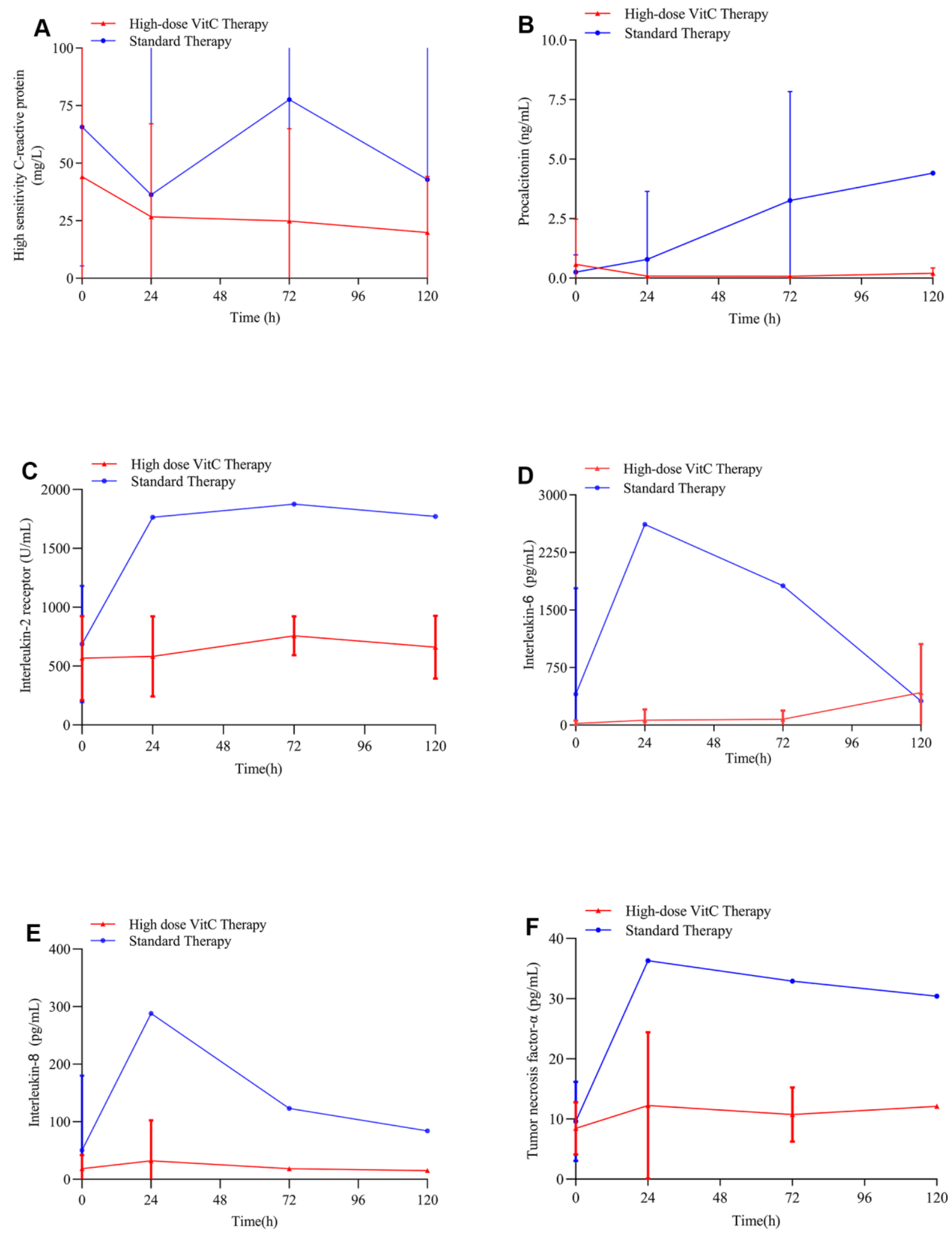

Figure 3. Changes in hs-CRP and PCT levels with therapy. (A) High-dose vitamin C reduced serum hs-CRP levels in COVID-19 patients; (B) High-dose vitamin C reduced serum PCT levels in COVID-19 patients; (C) High-dose vitamin C did not affect the serum IL-2R levels in COVID-19 patients remarkably; (D) High-dose vitamin C did not affect the serum IL-6 levels in COVID-19 patients remarkably; (E) High-dose vitamin C reduced serum IL-8 levels in COVID-19 patients; (F) High-dose vitamin C did not affect the serum TNF- $\alpha$ in COVID-19 patients remarkably. VitC: vitamin C; hs-CRP: high-sensitivity C-reactive protein; PCT: procalcitonin; IL-2R: interleukin-2 receptor; IL-6: interleukin-6; IL8: interleukin-8; TNF- $\alpha$ : tumor necrosis factor- $\alpha$ levels. 
Table 3. Summary of adverse events.

\begin{tabular}{lccc}
\hline Event & $\begin{array}{c}\text { Total } \\
(\mathbf{n = 7 6})\end{array}$ & $\begin{array}{c}\text { High-dose VitC } \\
(\mathbf{n = 4 6 )}\end{array}$ & $\begin{array}{c}\text { Standard therapy } \\
(\mathbf{n = 3 0})\end{array}$ \\
\hline Any adverse event & $37(48.7)$ & $19(41.3)$ & $18(60.0)$ \\
Lymphopenia & $7(9.2)$ & $3(6.5)$ & $4(13.3)$ \\
Leukopenia & $1(1.3)$ & $1(2.2)$ & 0 \\
Thrombocytopenia & $8(10.5)$ & $4(8.7)$ & $4(13.3)$ \\
Increased aspartate aminotransferase activity & $5(6.6)$ & $3(6.5)$ & $2(6.7)$ \\
Increased alanine aminotransferase activity & $3(3.9)$ & $2(4.3)$ & $1(3.3)$ \\
Increased total bilirubin level & $15(19.7)$ & $6(13.0)$ & $9(30.0)$ \\
Increased serum creatinine level & $6(7.9)$ & $3(6.5)$ & $3(10.0)$ \\
Increased creatine kinase isoenzyme-MB activity & $2(2.6)$ & $1(2.2)$ & $1(3.3)$ \\
Increased high sensitivity-cardiac troponin I level & $5(6.6)$ & $3(6.5)$ & $2(6.7)$ \\
Increased N-terminal pro-B-type natriuretic peptide level & $5(6.6)$ & $3(6.5)$ & $2(6.7)$ \\
Serious adverse event & $6(7.9)$ & $1(2.2)$ & $5(16.7)$ \\
Respiratory failure or ARDS & $5(6.6)$ & $1(2.2)$ & $4(13.3)$ \\
Shock & $2(2.6)$ & $1(2.2)$ & $1(3.3)$ \\
Sepsis & $2(2.6)$ & $1(2.2)$ & $1(3.3)$ \\
\hline
\end{tabular}

Data are $\mathrm{n}(\%)$. Adverse events that occurred in more than 1 patient through follow-up. Some patients had more than one adverse event. All deaths were caused by respiratory failure. ARDS: acute respiratory distress syndrome; VitC: vitamin C.

reduced serum IL-8 level compared with the standard therapy in COVID-19 patients (Figure 3E). The synergy of cytokines such as TNF- $\alpha$, interleukin-1 (IL-1), IL-6, and IL-8 can regulate the inflammatory cascade. Studies have shown that vitamin $\mathrm{C}$ reduced the production of chemokine such as IL-8, thereby reducing the inflammatory changes of lung injury caused by sepsis, and this reaction was associated with significantly lower mortality in critically ill patients with severe pneumonia $[30,34]$. Evidence has suggested that cytokine storms such as higher concentrations of IL-6, IL-8 and interleukin-10 (IL-10) were related to the prognosis of COVID-19 patients [41]. Treatment with high-dose vitamin $\mathrm{C}$ is associated with reduced hs-CRP, PCT, and IL-8 levels and can reduce inflammation and thus attenuate lung and systemic inflammation [30, 33, 34]. Also, our COVID-19 patients showed improved oxygen support status, which may lead to reduced mortality.

Epidemiology results showed that patients with severe and critical disease have relatively high mortality, and no effective treatment is available to significantly reduce mortality [42, 43]. Our study found that highdose vitamin $\mathrm{C}$ could significantly decrease mortality with COVID-19 as compared with standard therapy, so vitamin $\mathrm{C}$ may be an effective drug for COVID-19, especially for severe and critical cases.

Additionally, we found better clinical improvement with high-dose vitamin $\mathrm{C}$ therapy than standard therapy for patients $\leq 60$ years old and with low-flow oxygen, and serum hs-CRP level $<1 \mathrm{mg} / \mathrm{L}$. Thus, the use of high-dose vitamin $\mathrm{C}$ may have a certain subgroup selectivity, although the clinical improvement between high-dose vitamin $\mathrm{C}$ and standard therapy did not significantly differ (Supplementary Figure 2). Body weight is an important clinical indicator for many diseases. While many previous studies $[11,44,45]$ have confirmed that the body weight was not associated with the prognosis of patients with COVID-19. In addition, the effect of high-dose vitamin $\mathrm{C}$ on anti-oxidation and reducing inflammatory reaction did not show significant correlation with body weight based on recent studies $[30,46]$. Although we did not record the body weight of patients in baseline, the body weight might not affect the results of our study.

The incidence of adverse events was lower with highdose vitamin $C$ than standard therapy, without new adverse events, which suggests that high-dose vitamin $\mathrm{C}$ may be safe. Moreover, many studies have confirmed the safety of high-dose vitamin C. A study of high-dose vitamin $\mathrm{C}$ treatment in patients with severe sepsis and ARDS found no adverse events [31, 43]. Recent studies [8, 47, 48] reported that some patients with COVID-19 had lymphopenia, leukopenia, thrombocytopenia, liver function abnormality, abnormal myocardial zymography findings, and renal impairment. Therefore, the adverse events in our study were not associated with highdose vitamin $\mathrm{C}$ therapy. 
Physicians are exploring various drugs for COVID-19. Remdesivir, [13, 14] hydroxychloroquine/chloroquine [15-17] and corticosteroids [49] have been explored. Although most achieved a certain effect, they were accompanied by various adverse events such as arrhythmia, [18, 19] immunosuppressive effects, [49] liver and kidney damage, [13] and acute respiratory failure [13, 14]. Generally, serious adverse events have a great impact on the treatment effect, prognosis and quality of life of patients. High-dose vitamin $\mathrm{C}$ with an effective role and without adverse events might be a promising therapy for COVID-19.

This study has several limitations. First, although we did not observe differences at baseline between the two treatment groups, potential bias exists in this retrospective cohort study. For instance, the treatment patients received and the specific protocols of standard therapy were not controlled. Second, the results are less persuasive owing to the small sample size. Third, we did not collect data on plasma vitamin $\mathrm{C}$ level to confirm whether the plasma level is a predictor in patients with COVID-19.

\section{CONCLUSIONS}

In summary, high-dose vitamin $\mathrm{C}$ may reduce inflammatory reaction, improve oxygen support status and reduce mortality in COVID-19 patients, without adverse events. Also, it may be effective for certain subgroups with severe and critical disease and older patients. High-dose vitamin $\mathrm{C}$ may be a promising therapy for COVID-19.

\section{MATERIALS AND METHODS}

\section{Study design and participants}

This was a retrospective cohort study of in-hospital patients with COVID-19 from January 31, 2020 to March 28, 2020 diagnosed and treated by our medical group in Tongji Hospital, Tongji Medical College, Huazhong University of Science and Technology. This study was based on the approved guidelines for COVID-19 [50]. Informed consent was waived by the board due to the retrospective nature of the study.

Patients with COVID-19 were diagnosed according to Diagnosis and Treatment of Pneumonia Infected by Novel Coronavirus issued by the National Health Commission of China [51]. We excluded patients who were younger than 18 years, allergic to vitamin $\mathrm{C}$, died within $24 \mathrm{hr}$ after admission, or were pregnant and/or lactating. Other patients were classified into two groups: high-dose vitamin $\mathrm{C}$ therapy and standard therapy. Patients were informed of the rationality of the treatment plan and potential side effects. Only patients with consent were treated. Patients in the high-dose vitamin $C$ therapy group received standard therapy [51] as well as a 5-day course of a loading dose of $6 \mathrm{~g}$ added to $5 \%$ glucose solution for intravenous high-dose vitamin $\mathrm{C}$ infusion lasting over $60 \mathrm{~min}$ per $12 \mathrm{hr}$ on the first day, plus $6 \mathrm{~g}$ added to $5 \%$ glucose solution for intravenous high-dose vitamin $\mathrm{C}$ infusion lasting over 60 min per day for the following 4 days. Patients receiving standard therapy alone were included in the standard therapy group. The standard therapy was based on the Diagnosis and Treatment Protocol for Novel Coronavirus Pneumonia issued by the National Health Commission of China [51]. As suggested in the guideline, standard therapy included daily monitoring, routine laboratory tests (blood count, urea, creatinine, liver enzymes, and other related biomarkers), effective respiratory therapy (nasal cannula oxygen therapy, mask oxygen therapy or high-flow nasal oxygen therapy, if necessary, noninvasive ventilation), and surveillance of vital parameters according to the patient's condition. The addition of other therapies such as antibiotics, corticosteroids, immunomodulators and other antivirals (e.g., Lopinavir/Ritonavir, Ribavirin) according to the assessment of the physicians were also included in the standard therapy.

This study lasted from the time of hospital admission to discharge or death in hospital occurred. The hospital electronic medical records included the data of all patients from admission to discharge or death in hospital, the data during treatment with high-dose vitamin $\mathrm{C}$ was also included. In addition, the 28-day death of patients was recorded.

\section{Outcomes}

The primary outcome was 28-day mortality and clinical improvement. The secondary outcome was change in oxygen support status after treatment. Clinical improvement was defined as a decrease of at least 2 points from baseline to day 28 or discharge according to the seven-category ordinal scale. The ordinal scale is based on the endpoints in patients with severe influenza, [51-53] which consists of 1) no hospitalization with the resumption of normal activities; 2) no hospitalization but unable to resume normal activities; 3 ) hospitalization but not requiring supplemental oxygen; 4) hospitalization and requiring supplemental oxygen; 5) hospitalization and requiring nasal high-flow oxygen therapy and/or noninvasive mechanical ventilation; 6) hospitalization and requiring extracorporeal membrane oxygenation and/or invasive mechanical ventilation; and 7) death.

\section{Statistical analysis}

Information for patients including clinical characteristics, laboratory data and outcomes were 
collected from medical records. Continuous variables for baseline characteristics are described with the median (interquartile range [IQR]) and categorical variables with frequency (percentage). Continuous variables were analyzed using Student's $t$ or MannWhitney $U$ tests and categorical variables were analyzed with chi-squared or Fisher' $\mathrm{s}$ exact tests. Clinical improvement and all-cause mortality were analyzed by Kaplan-Meier analysis with a log-rank test. Hazard ratios and $95 \%$ confidence intervals (CIs) were estimated. Data were analyzed by using SPSS 20.0. $P<0.05$ was considered statistically significant.

\section{Abbreviations}

COVID-19: Coronavirus disease 2019; WHO: World Health Organization; ARDS: acute respiratory distress syndrome; IQR: interquartile range; CIs: confidence intervals; hs-CRP: high-sensitivity C-reactive protein; PCT: procalcitonin; IL-1: interleukin-1; IL-2R: interleukin-2 receptor; IL-6: interleukin-6; IL-8: interleukin-8; IL-10: interleukin-10; TNF- $\alpha$ : tumor necrosis factor- $\alpha$.

\section{AUTHOR CONTRIBUTIONS}

Conceptualization, Gang Wang; Methodology, Jianrui Lv and Xiaorong Ma; Software, Yonghong Guo and Dexin Zhang; Validation, Huiyun Yang and Wei Jiang; Formal Analysis, Dengfeng $\mathrm{Gao}$ and Min $\mathrm{Xu}$; Investigation, Fuxue Deng; Resources, Guozhi Xia; Data Curation, Ziwei Lu and Lv Lv; Writing - Original Draft Preparation, Min Xu; Writing - Review and Editing, Dengfeng Gao and Shouping Gong; Visualization, Min $\mathrm{Xu}$ and $\mathrm{Lv} \mathrm{Lv}$; Supervision, Dengfeng Gao and Shouping Gong; Project Administration, Shouping Gong.

\section{CONFLICTS OF INTEREST}

The authors declare that they have no conflicts of interest.

\section{FUNDING}

This research did not receive any specific grant from funding agencies in the public, commercial, or not-forprofit sectors.

\section{REFERENCES}

1. Zhu N, Zhang D, Wang W, Li X, Yang B, Song J, Zhao X, Huang B, Shi W, Lu R, Niu P, Zhan F, Ma X, et al, and China Novel Coronavirus Investigating and Research Team. A novel coronavirus from patients with pneumonia in China, 2019. N Engl J Med. 2020; 382:727-33.
https://doi.org/10.1056/NEJMoa2001017 PMID:31978945

2. Lu H, Stratton CW, Tang YW. Outbreak of pneumonia of unknown etiology in Wuhan, China: the mystery and the miracle. J Med Virol. 2020; 92:401-02. https://doi.org/10.1002/jmv.25678 PMID:31950516

3. Wang C, Horby PW, Hayden FG, Gao GF. A novel coronavirus outbreak of global health concern. Lancet. 2020; 395:470-73. https://doi.org/10.1016/S0140-6736(20)30185-9 PMID:31986257

4. Wuhan Municipal Health Commission. Report of novel coronavirus-infected pneumonia in China (in Chinese). 2020. http://wjw.wuhan.gov.cn

5. Hui DS, I Azhar E, Madani TA, Ntoumi F, Kock R, Dar O, Ippolito G, Mchugh TD, Memish ZA, Drosten C, Zumla A, Petersen E. The continuing 2019-nCoV epidemic threat of novel coronaviruses to global health - the latest 2019 novel coronavirus outbreak in Wuhan, China. Int J Infect Dis. 2020; 91:264-66. https://doi.org/10.1016/j.ijid.2020.01.009 PMID:31953166

6. World Health Organization. Coronavirus disease (COVID-19) panndemic. 2020. https://www.who.int/ docs/default-source/coronaviruse/situationreports/20200702-covid-19-sitrep164.pdf?sfvrsn=ac074f58 2

7. Huang C, Wang Y, Li X, Ren L, Zhao J, Hu Y, Zhang L, Fan G, Xu J, Gu X, Cheng Z, Yu T, Xia J, et al. Clinical features of patients infected with 2019 novel coronavirus in Wuhan, China. Lancet. 2020; 395:497-506. https://doi.org/10.1016/S0140-6736(20)30183-5 PMID:31986264

8. Chen N, Zhou M, Dong X, Qu J, Gong F, Han Y, Qiu Y, Wang J, Liu Y, Wei Y, Xia J, Yu T, Zhang X, Zhang L. Epidemiological and clinical characteristics of 99 cases of 2019 novel coronavirus pneumonia in Wuhan, China: a descriptive study. Lancet. 2020; 395:507-13. https://doi.org/10.1016/S0140-6736(20)30211-7 PMID:32007143

9. Wang D, Hu B, Hu C, Zhu F, Liu X, Zhang J, Wang B, Xiang $\mathrm{H}$, Cheng Z, Xiong $\mathrm{Y}$, Zhao $\mathrm{Y}$, Li Y, Wang X, Peng Z. Clinical characteristics of 138 hospitalized patients with 2019 novel coronavirus-infected pneumonia in Wuhan, China. JAMA. 2020; 323:1061-69.

https://doi.org/10.1001/jama.2020.1585 PMID: $\underline{32031570}$

10. Chen T, Wu D, Chen H, Yan W, Yang D, Chen G, Ma K, Xu D, Yu H, Wang H, Wang T, Guo W, Chen J, et al. Clinical characteristics of 113 deceased patients with coronavirus disease 2019: retrospective study. BMJ. 2020; 368:m1091. 
https://doi.org/10.1136/bmj.m1091

PMID:32217556

11. Zhou F, Yu T, Du R, Fan G, Liu Y, Liu Z, Xiang J, Wang Y, Song B, Gu X, Guan L, Wei Y, Li H, et al. Clinical course and risk factors for mortality of adult inpatients with COVID-19 in Wuhan, China: a retrospective cohort study. Lancet. 2020; 395:1054-62.

https://doi.org/10.1016/S0140-6736(20)30566-3 PMID:32171076

12. Richardson S, Hirsch JS, Narasimhan M, Crawford JM, McGinn T, Davidson KW, Barnaby DP, Becker LB, Chelico JD, Cohen SL, Cookingham J, Coppa K, Diefenbach MA, et al, and the Northwell COVID-19 Research Consortium. Presenting characteristics, comorbidities, and outcomes among 5700 patients hospitalized with COVID-19 in the New York city area. JAMA. 2020; 323:2052-59.

https://doi.org/10.1001/jama.2020.6775

PMID:32320003

13. Goldman JD, Lye DC, Hui DS, Marks KM, Bruno R, Montejano R, Spinner CD, Galli M, Ahn MY, Nahass RG, Chen YS, SenGupta D, Hyland RH, et al, and GS-US-5405773 Investigators. Remdesivir for 5 or 10 days in patients with severe covid-19. N Engl J Med. 2020; 383:1827-37.

https://doi.org/10.1056/NEJMoa2015301 PMID:32459919

14. Wang Y, Zhang D, Du G, Du R, Zhao J, Jin Y, Fu S, Gao L, Cheng Z, Lu Q, Hu Y, Luo G, Wang K, et al. Remdesivir in adults with severe COVID-19: a randomised, doubleblind, placebo-controlled, multicentre trial. Lancet. 2020; 395:1569-78.

https://doi.org/10.1016/S0140-6736(20)31022-9

PMID:32423584

15. Wang M, Cao R, Zhang L, Yang X, Liu J, Xu M, Shi Z, Hu Z, Zhong W, Xiao G. Remdesivir and chloroquine effectively inhibit the recently emerged novel coronavirus (2019nCoV) in vitro. Cell Res. 2020; 30:269-71.

https://doi.org/10.1038/s41422-020-0282-0

PMID:32020029

16. Chen Z, Hu J, Zhang Z, Jiang S, Han S, Yan D, Zhuang R, $\mathrm{Hu}$ B, Zhang Z. Efficacy of hydroxychloroquine in patients with COVID-19: results of a randomized clinical trial. medRxiv. 2020.

https://doi.org/10.1101/2020.03.22.20040758

17. Boulware DR, Pullen MF, Bangdiwala AS, Pastick KA, Lofgren SM, Okafor EC, Skipper CP, Nascene AA, Nicol MR, Abassi M, Engen NW, Cheng MP, LaBar D, et al. A randomized trial of hydroxychloroquine as postexposure prophylaxis for covid-19. N Engl J Med. 2020; 383:517-25.

https://doi.org/10.1056/NEJMoa2016638

PMID:32492293
18. Borba MG, Val FF, Sampaio VS, Alexandre MA, Melo GC, Brito M, Mourão MP, Brito-Sousa JD, Baía-da-Silva D, Guerra MV, Hajjar LA, Pinto RC, Balieiro AA, et al, and CloroCovid-19 Team. Effect of high vs low doses of chloroquine diphosphate as adjunctive therapy for patients hospitalized with severe acute respiratory syndrome coronavirus 2 (SARS-CoV-2) infection: a randomized clinical trial. JAMA Netw Open. 2020; 3:e208857.

https://doi.org/10.1001/jamanetworkopen.2020.8857 PMID:32330277

19. Chorin E, Dai M, Shulman E, Wadhwani L, Bar-Cohen R, Barbhaiya C, Aizer A, Holmes D, Bernstein S, Spinelli M, Park DS, Chinitz LA, Jankelson L. The QT interval in patients with COVID-19 treated with hydroxychloroquine and azithromycin. Nat Med. 2020; 26:808-09.

https://doi.org/10.1038/s41591-020-0888-2

PMID:32488217

20. Armour J, Tyml K, Lidington D, Wilson JX. Ascorbate prevents microvascular dysfunction in the skeletal muscle of the septic rat. J Appl Physiol (1985). 2001; 90:795-803.

https://doi.org/10.1152/jappl.2001.90.3.795 PMID:11181585

21. Wu F, Wilson JX, Tyml K. Ascorbate protects against impaired arteriolar constriction in sepsis by inhibiting inducible nitric oxide synthase expression. Free Radic Biol Med. 2004; 37:1282-89.

https://doi.org/10.1016/j.freeradbiomed.2004.06.025 PMID:15451067

22. Chakrabarty S, Nandi A, Mukhopadhyay CK, Chatterjee IB. Protective role of ascorbic acid against lipid peroxidation and myocardial injury. Mol Cell Biochem. 1992; 111:41-47.

https://doi.org/10.1007/BF00229572

PMID:1588941

23. Mukhopadhyay CK, Ghosh MK, Chatterjee IB. Ascorbic acid prevents lipid peroxidation and oxidative damage of proteins in Guinea pig extrahepatic tissue microsomes. Mol Cell Biochem. 1995; 142:71-78. https://doi.org/10.1007/BF00928915 PMID:7753044

24. Li F. Mechanism of rescue of Keshan disease with highdose vitamin C. Zhongguo Di Fang Bing Fang Zhi Za Zhi. 1996; 11:33-36.

25. Keshan Disease Laboratory of Xi'an Medical College. Clinical effect and mechanism of high-dose vitamin $C$ for severe Keshan disease. Zhonghua Nei Ke Za Zhi. 1961; 9:436.

26. Wang S. Changes in thinking and the establishment of high-dose vitamin C therapy-commemorating the 60th anniversary of the discovery of Keshan disease and the 
35th anniversary of the high-dose vitamin C therapy. Di Fang Bing Tong Bao. 1996; 11:7.

27. Marik PE, Khangoora V, Rivera R, Hooper MH, Catravas J. Hydrocortisone, vitamin $\mathrm{C}$, and thiamine for the treatment of severe sepsis and septic shock: a retrospective before-after study. Chest. 2017; 151:1229-38.

https://doi.org/10.1016/j.chest.2016.11.036 PMID:27940189

28. Fowler AA 3rd, Truwit JD, Hite RD, Morris PE, DeWilde C, Priday A, Fisher B, Thacker LR 2nd, Natarajan R, Brophy DF, Sculthorpe R, Nanchal R, Syed A, et al. Effect of vitamin $C$ infusion on organ failure and biomarkers of inflammation and vascular injury in patients with sepsis and severe acute respiratory failure: the CITRIS-ALI randomized clinical trial. JAMA. 2019; 322:1261-70.

https://doi.org/10.1001/jama.2019.11825

PMID:31573637

29. Fowler AA 3rd, Syed AA, Knowlson S, Sculthorpe R, Farthing D, DeWilde C, Farthing CA, Larus TL, Martin E, Brophy DF, Gupta S, Fisher BJ, Natarajan R, and Medical Respiratory Intensive Care Unit Nursing. Phase I safety trial of intravenous ascorbic acid in patients with severe sepsis. J Transl Med. 2014; 12:32.

https://doi.org/10.1186/1479-5876-12-32

PMID:24484547

30. Kim WY, Jo EJ, Eom JS, Mok J, Kim MH, Kim KU, Park HK, Lee MK, Lee K. Combined vitamin C, hydrocortisone, and thiamine therapy for patients with severe pneumonia who were admitted to the intensive care unit: propensity score-based analysis of a beforeafter cohort study. J Crit Care. 2018; 47:211-18.

https://doi.org/10.1016/j.jcrc.2018.07.004

PMID:30029205

31. Carr AC, Rosengrave PC, Bayer S, Chambers S, Mehrtens J, Shaw GM. Hypovitaminosis C and vitamin C deficiency in critically ill patients despite recommended enteral and parenteral intakes. Crit Care. 2017; 21:300.

https://doi.org/10.1186/s13054-017-1891-y PMID:29228951

32. Borrelli E, Roux-Lombard P, Grau GE, Girardin E, Ricou B, Dayer J, Suter PM. Plasma concentrations of cytokines, their soluble receptors, and antioxidant vitamins can predict the development of multiple organ failure in patients at risk. Crit Care Med. 1996; 24:392-97.

https://doi.org/10.1097/00003246-199603000-00006

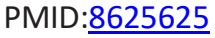

33. Hemilä $H$, Louhiala P. Vitamin C for preventing and treating pneumonia. Cochrane Database Syst Rev. 2013; 8:CD005532.
https://doi.org/10.1002/14651858.CD005532.pub3 PMID:23925826

34. Fisher BJ, Seropian IM, Kraskauskas D, Thakkar JN, Voelkel NF, Fowler AA 3rd, Natarajan R. Ascorbic acid attenuates lipopolysaccharide-induced acute lung injury. Crit Care Med. 2011; 39:1454-60. https://doi.org/10.1097/CCM.0b013e3182120cb8 PMID:21358394

35. Jensen JU, Heslet L, Jensen TH, Espersen K, Steffensen $P$, Tvede $M$. Procalcitonin increase in early identification of critically ill patients at high risk of mortality. Crit Care Med. 2006; 34:2596-602. https://doi.org/10.1097/01.CCM.0000239116.01855.6 1 PMID: $\underline{16915118}$

36. Chen L, Liu HG, Liu W, Liu J, Liu K, Shang J, Deng Y, Wei S. [Analysis of Clinical Features of 29 Patients With 2019 Novel Coronavirus Pneumonia]. Zhonghua Jie He He Hu Xi Za Zhi. 2020; 43:203-08.

37. Lobo SM, Lobo FR, Bota DP, Lopes-Ferreira F, Soliman HM, Mélot C, Vincent JL. C-reactive protein levels correlate with mortality and organ failure in critically ill patients. Chest. 2003; 123:2043-49.

https://doi.org/10.1378/chest.123.6.2043

PMID:12796187

38. Vincent JL, Donadello K, Schmit X. Biomarkers in the critically ill patient: C-reactive protein. Crit Care Clin. 2011; 27:241-51.

https://doi.org/10.1016/j.ccc.2010.12.010 PMID:21440199

39. Wilson JX. Mechanism of action of vitamin C in sepsis: ascorbate modulates redox signaling in endothelium. Biofactors. 2009; 35:5-13. https://doi.org/10.1002/biof.7 PMID:19319840

40. May JM, Harrison FE. Role of vitamin C in the function of the vascular endothelium. Antioxid Redox Signal. 2013; 19:2068-83.

https://doi.org/10.1089/ars.2013.5205 PMID:23581713

41. Li Q, Xu W, Li WX, Huang CL, Chen L. Dynamics of cytokines and lymphocyte subsets associated with the poor prognosis of severe COVID-19. Eur Rev Med Pharmacol Sci. 2020; 24:12536-44.

https://doi.org/10.26355/eurrev 20201224051 PMID:33336774

42. Yang $X, Y u Y, X u$ J, Shu $H$, Xia J, Liu H, Wu Y, Zhang L, Yu $Z$, Fang $M, Y u T$, Wang $Y$, Pan $S$, et al. Clinical course and outcomes of critically ill patients with SARS-CoV-2 pneumonia in Wuhan, China: a single-centered, retrospective, observational study. Lancet Respir Med. 2020; 8:475-81. https://doi.org/10.1016/S2213-2600(20)30079-5 PMID:32105632 
43. Guan WJ, Ni ZY, Hu Y, Liang WH, Ou CQ, He JX, Liu L, Shan H, Lei CL, Hui DS, Du B, Li L, Zeng G, et al, and China Medical Treatment Expert Group for Covid-19. Clinical characteristics of coronavirus disease 2019 in China. N Engl J Med. 2020; 382:1708-20.

https://doi.org/10.1056/NEJMoa2002032

PMID:32109013

44. Mikami T, Miyashita $H$, Yamada $T$, Harrington $M$, Steinberg D, Dunn A, Siau E. Risk factors for mortality in patients with COVID-19 in New York city. J Gen Intern Med. 2020; 136:17-26.

https://doi.org/10.1007/s11606-020-05983-z

PMID:32607928

45. Du RH, Liang LR, Yang CQ, Wang W, Cao TZ, Li M, Guo GY, Du J, Zheng CL, Zhu Q, Hu M, Li XY, Peng P, Shi HZ. Predictors of mortality for patients with COVID-19 pneumonia caused by SARS-CoV-2: a prospective cohort study. Eur Respir J. 2020; 55:2000524.

https://doi.org/10.1183/13993003.00524-2020

PMID:32269088

46. Ahn JH, Oh DK, Huh JW, Lim CM, Koh Y, Hong SB. Vitamin $\mathrm{C}$ alone does not improve treatment outcomes in mechanically ventilated patients with severe sepsis or septic shock: a retrospective cohort study. J Thorac Dis. 2019; 11:1562-70.

https://doi.org/10.21037/itd.2019.03.03

PMID:31179100

47. $\mathrm{Xu} X W$, Wu XX, Jiang XG, Xu KJ, Ying $L, M a C L$, Li SB, Wang HY, Zhang S, Gao HN, Sheng JF, Cai HL, Qiu YQ, Li $\sqcup$. Clinical findings in a group of patients infected with the 2019 novel coronavirus (SARS-Cov-2) outside of Wuhan, China: retrospective case series. BMJ. 2020; 368:m606.

https://doi.org/10.1136/bmj.m606 PMID: 32075786

48. Holshue $\mathrm{ML}$, DeBolt $\mathrm{C}$, Lindquist $\mathrm{S}$, Lofy $\mathrm{KH}$, Wiesman J, Bruce H, Spitters C, Ericson K, Wilkerson S, Tural A, Diaz
G, Cohn A, Fox L, et al, and Washington State 2019nCoV Case Investigation Team. First case of 2019 novel coronavirus in the United States. N Engl J Med. 2020; 382:929-36.

https://doi.org/10.1056/NEJMoa2001191

PMID:32004427

49. Russell CD, Millar JE, Baillie JK. Clinical evidence does not support corticosteroid treatment for 2019-nCoV lung injury. Lancet. 2020; 395:473-75. https://doi.org/10.1016/S0140-6736(20)30317-2 PMID:32043983

50. Comprehensive treatment and management of corona virus disease 2019: expert consensus statement from Shanghai City. Zhonghua Chuan Ran Bing Za Zhi. 2020; 38:134-38.

51. Diagnosis and Treatment Protocol for Novel Coronavirus Pneumonia (Trial Version 7). 2020. http://www.gov.cn/zhengce/zhengceku/202003/04/content 5486705.htm

52. Wang $Y$, Fan G, Salam A, Horby P, Hayden FG, Chen C, Pan J, Zheng J, Lu B, Guo L, Wang C, Cao B. Comparative effectiveness of combined favipiravir and oseltamivir therapy versus oseltamivir monotherapy in critically ill patients with influenza virus infection. J Infect Dis. 2020; 221:1688-98.

https://doi.org/10.1093/infdis/iiz656

PMID:31822885

53. Beigel JH, Tebas $P$, Elie-Turenne MC, Bajwa E, Bell TE, Cairns CB, Shoham S, Deville JG, Feucht E, Feinberg J, Luke T, Raviprakash K, Danko J, et al, and IRC002 Study Team. Immune plasma for the treatment of severe influenza: an open-label, multicentre, phase 2 randomised study. Lancet Respir Med. 2017; 5:500-11. https://doi.org/10.1016/S2213-2600(17)30174-1 PMID:28522352 


\section{SUPPLEMENTARY MATERIALS}

\section{Supplementary Figures}

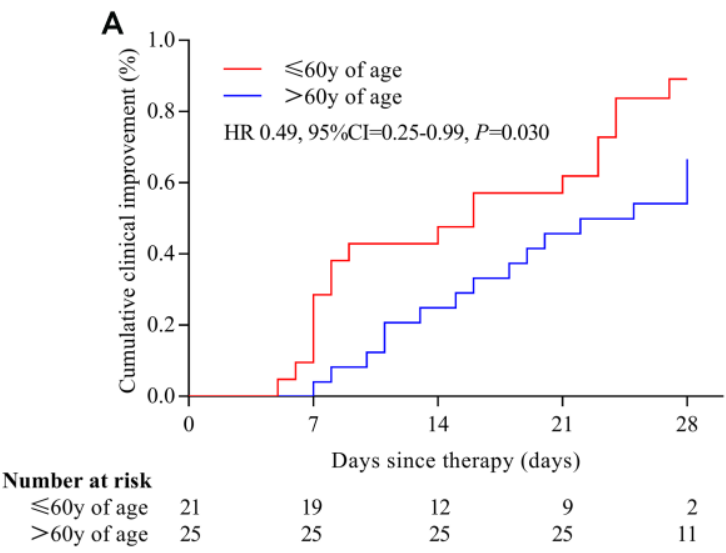

B

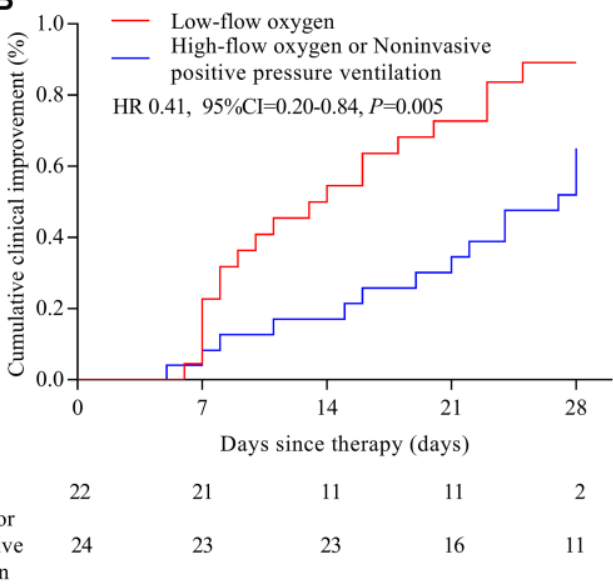

$\begin{array}{llllll}\begin{array}{l}\text { Number at risk } \\ \text { Low-flow oxygen } \\ \text { High-flow oxygen or }\end{array} & 22 & 21 & 11 & 11 & 2 \\ \begin{array}{l}\text { Noninvasive positive } \\ \text { pressure ventilation }\end{array} & 24 & 23 & 23 & 16 & 11\end{array}$



Supplementary Figure 1. Cumulative incidence of clinical improvement in high-dose vitamin C therapy group. (A) In the highdose vitamin C group, clinical improvement was better for patients $\leq 60$ years old than others (HR=0.49, 95\% Cl, 0.25-0.99); (B) In the highdose vitamin C group, clinical improvement was better for patients who received low-flow oxygen $(\mathrm{HR}=0.41,95 \% \mathrm{Cl}, 0.20-0.84)$; $(\mathrm{C})$ In the high-dose vitamin C group, clinical improvement was better for those with serum hs-CRP $<1 \mathrm{mg} / \mathrm{L}(\mathrm{HR}=0.26,95 \% \mathrm{Cl}, 0.07-0.94)$. Hs-CRP: highsensitivity C-reactive protein. 


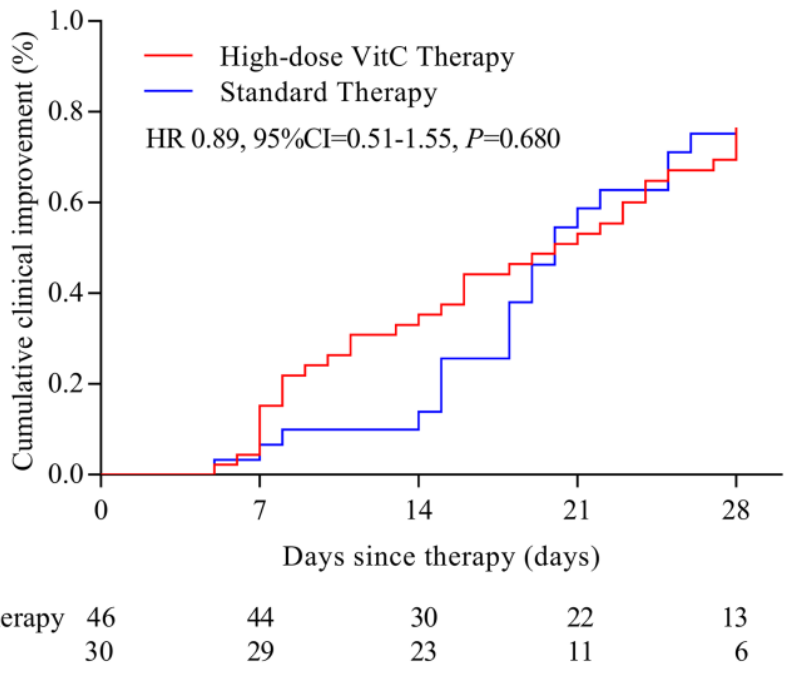

Supplementary Figure 2. Overall cumulative incidence of clinical improvement. The clinical improvement between high-dose vitamin $\mathrm{C}$ and standard therapy did not significantly differ ( $\mathrm{HR}=0.89,95 \% \mathrm{Cl}, 0.51-1.55)$. VitC: vitamin C. 


\section{Supplementary Table}

Supplementary Table 1. Laboratory data for patients at baseline.

\begin{tabular}{|c|c|c|c|c|}
\hline Characteristic & $\begin{array}{c}\text { Total } \\
(\mathrm{n}=76)\end{array}$ & $\begin{array}{c}\text { High-dose VitC } \\
(n=46)\end{array}$ & $\begin{array}{c}\text { Standard therapy } \\
(\mathrm{n}=\mathbf{3 0})\end{array}$ & $P$ value \\
\hline $\begin{array}{l}\text { White-cell count }(\times 10-9 / \mathrm{L})- \\
\text { median }(\mathrm{IQR})\end{array}$ & $6.7(4.5-9.1)$ & $6.9(5.0-9.8)$ & $6.2(4.4-8.5)$ & 0.276 \\
\hline $\begin{array}{l}\text { Lymphocyte count }(\times 10-9 / \mathrm{L})- \\
\text { median (IQR) }\end{array}$ & $0.9(0.7-1.4)$ & $1.0(0.8-1.6)$ & $0.9(0.6-1.3)$ & 0.224 \\
\hline $\begin{array}{l}\text { Platelet count }\left(\times 10^{-9 / \mathrm{L})}-\right. \\
\text { median }(\mathrm{IQR})\end{array}$ & $210(168-275)$ & $222(172-283)$ & $186(152-231)$ & 0.115 \\
\hline $\begin{array}{l}\text { Alanine aminotransferase (U/L) } \\
\text { - median (IQR) }\end{array}$ & $22(14-37)$ & $21(14-37)$ & $25(15-38)$ & 0.595 \\
\hline $\begin{array}{l}\text { Aspartate aminotransferase }(\mathrm{U} / \mathrm{L}) \\
\text { - median (IQR) }\end{array}$ & $28(20-43)$ & $26(17-37)$ & $34(23-49)$ & 0.059 \\
\hline $\begin{array}{l}\text { Serum creatinine }(\mu \mathrm{mol} / \mathrm{L})- \\
\text { median }(\mathrm{IQR})\end{array}$ & $67(60-77)$ & $66(61-72)$ & $70(56-83)$ & 0.431 \\
\hline $\begin{array}{l}\text { High sensitivity-cardiac troponin } \\
\text { I }(\mathrm{pg} / \mathrm{mL}) \text { - median (IQR) }\end{array}$ & $3.5(2.0-13.6)$ & $3.2(1.9-15.3)$ & $4.3(2.3-10.2)$ & 0.765 \\
\hline $\begin{array}{l}\text { N-terminal pro-B-type natriuretic } \\
\text { peptide }(\mathrm{pg} / \mathrm{mL}) \text { - median (IQR) }\end{array}$ & $113(47-353)$ & $113(54-675)$ & $105(30-217)$ & 0.258 \\
\hline $\begin{array}{l}\text { Creatine Kinase Isoenzyme-MB } \\
(\mathrm{ng} / \mathrm{mL}) \text { - median (IQR) }\end{array}$ & $0.9(0.4-2.2)$ & $0.7(0.4-2.0)$ & $1.3(0.3-2.6)$ & 0.754 \\
\hline $\begin{array}{l}\text { Lactate dehydrogenase (U/L) - } \\
\text { median (IQR) }\end{array}$ & $261(206-365)$ & $241(195-356)$ & $309(229-385)$ & 0.138 \\
\hline $\begin{array}{l}\text { High sensitivity C-reactive } \\
\text { protein }(\mathrm{mg} / \mathrm{L}) \text { - median (IQR) }\end{array}$ & $9.7(1.6-76.6)$ & $53.9(10.0-115.8)$ & $18.7(3.0-84.2)$ & 0.129 \\
\hline $\begin{array}{l}\text { Procalcitonin }(\mathrm{ng} / \mathrm{mL}) \text { - median } \\
\text { (IQR) }\end{array}$ & $0.04(0.02-0.17)$ & $0.07(0.03-0.11)$ & $0.05(0.03-0.12)$ & 0.403 \\
\hline $\begin{array}{l}\text { Interleukin-2 receptor }(\mathrm{U} / \mathrm{mL})- \\
\text { median (IQR) }\end{array}$ & $490(241-899)$ & $630(356-793)$ & $508(281-853)$ & 0.353 \\
\hline $\begin{array}{l}\text { Interleukin-6 }(\mathrm{pg} / \mathrm{mL}) \text { - median } \\
\text { (IQR) }\end{array}$ & $4.70(1.93-20.02)$ & $3.70(1.78-37.79)$ & $4.69(1.94-23.49)$ & 0.338 \\
\hline $\begin{array}{l}\text { Interleukin-8 (pg/mL) — median } \\
\text { (IQR) }\end{array}$ & $11.6(6.8-20.4)$ & $10.3(5.8-26.5)$ & $11.3(6.4-20.4)$ & 0.414 \\
\hline $\begin{array}{l}\text { Tumor necrosis factor- } \alpha(\mathrm{pg} / \mathrm{mL}) \\
\text { - median (IQR) }\end{array}$ & $7.3(5.6-10.1)$ & $8.1(5.2-10.7)$ & $7.7(5.6-10.3)$ & 0.472 \\
\hline pO2 $(\mathrm{mmHg})-\operatorname{median}(\mathrm{IQR})$ & $126.7(124.3-129.6)$ & $126.7(124.0-130.9)$ & $126.7(124.6-128.3)$ & 0.577 \\
\hline $\mathrm{pCO} 2(\mathrm{mmHg})-\operatorname{median}(\mathrm{IQR})$ & $40.1(39.2-41.0)$ & $40.0(39.2-41.2)$ & $40.3(39.3-40.9)$ & 0.992 \\
\hline $\mathrm{SO} 2 \%(\%)-\operatorname{median}(\mathrm{IQR})$ & $91.2(88.7-95.5)$ & $92.9(88.0-96.0)$ & $90.8(89.0-92.9)$ & 0.414 \\
\hline $\begin{array}{l}\text { TCO2 }(\mathrm{mmol} / \mathrm{L}) \text { - median } \\
(\mathrm{IQR})\end{array}$ & $28.2(24.5-31.7)$ & $27.9(23.8-30.6)$ & $29.4(26.3-32.3)$ & 0.122 \\
\hline
\end{tabular}

IQR: interquartile range; VitC: vitamin C. 